\title{
Gender Equality in Asia-Pacific: Reflections on the Beijing+25 Review
}

\author{
Cai Cai ${ }^{\dagger}$ and Bharat Dahiya ${ }^{*}$
}

\section{Abstract}

This article reviews the 25-year progress made in implementing the 'Beijing Platform for Action' and the challenges that remain towards achieving gender equality in the Asia-Pacific region. Adopted in 1995 at the Fourth World Conference on Women, the 'Beijing Platform for Action' has been hailed as the most progressive policy blueprint for gender equality and women's empowerment. In November 2019, over 600 participants from 54 countries, comprising representatives from Governments, international organisations and civil society organisations attended the Asia-Pacific Ministerial Conference on the Beijing+25 Review in Bangkok. The delegations reviewed the "achievements, challenges and priority areas for realizing gender equality and women's empowerment" (UNESCAP, 2019a:1) in Asia-Pacific. For 25 years, since the adoption of the "Beijing Platform for Action', Asia-Pacific has witnessed significant progress in girls' education and women's health. Unprecedented progress has been made in and reducing maternal deaths and enhancing women's representation in national parliaments and local governments in several countries. However, there are some enduring challenges, including women's economic empowerment and political participation, and violence against women. Whilst women play a pivotal role in protecting the environment and natural resources, they have been underrepresented in environment-related decision making and negotiations. Accordingly, the key actions outlined by the 'Asia-Pacific Declaration on Advancing Gender Equality and Women's Empowerment: Beijing+25 Review' cover a wide range of issues, from women's economic empowerment, political participation, to women's full and effective participation in environment conservation, climate action and peace building process.

Keywords: Gender Equality; Beijing Platform for Action; Beijing+25 Review; Asia-Pacific

\footnotetext{
${ }^{+}$Chief, Gender Equality and Social Inclusion Section, Social Development Division, United Nations Economic and Social Commission for Asia and the Pacific (UNESCAP), Rajadamnern Nok Avenue, Bangkok 10200, Thailand, Email:caic@un.org

${ }^{*}$ Corresponding Author, Email: bharatdahiya.tu@gmail.com

$¥$ Director, Research Center for Sustainable Development and Innovation, School of Global Studies, Thammasat University, Learning and Laboratory Building, Piyachart 2, 99 Moo 18 Klong Luang, Rangsit, Pathumthani 12121 Thailand

Disclaimer: The views expressed herein are those of the authors and do not necessarily reflect the views of the United Nations.

(C) 2020 Cai \& Dahiya. This is an Open Access article distributed under the terms of the Creative Commons Attribution License (http://creativecommons.org/licenses/by/2.0), which permits unrestricted use, distribution, and reproduction in any medium, provided the original work is properly cited.
} 


\section{Introduction}

The objective of this article is to review the 25year progress made in implementing the 'Beijing Platform for Action' and the challenges that remain toward achieving gender equality in the Asia-Pacific region. The year 2020 marks a quarter-century of the Fourth World Conference on Women that was held in China and the concomitant adoption of the 'Beijing Declaration and Platform for Action' in $1995^{1}$ (United Nations 1995, 2020a). The Beijing+25 Review was conducted at an important time. The 20192020 biennium is special considering the convergence of three milestones: 30-year anniversary of Convention on the Elimination of All Forms of Discrimination against Women, a quarter-century of Beijing Platform for Action, and the 20-year anniversary of the UN Security Council Resolution 1325 on Women, Peace and Security.

In November 2019, the Asian and Pacific countries celebrated the adoption of the landmark global gender commitments-'Beijing Declaration and Platform for Action', at the AsiaPacific Ministerial Conference on the Beijing+25 Review in Bangkok. Organised by the United Nations Economic and Social Commission for Asia and the Pacific (UNESCAP) in collaboration with UN Women, the Conference had the following objectives:

- "Assess progress and challenges to the implementation of the Beijing Declaration and Platform for Action in Asia and the Pacific over the past 5 years;

- Review good practices, lessons learned, priority actions required to realise gender equality and the empowerment of women by 2030 , as well as address emerging areas that impact on women's empowerment;

- Provide a platform to explore policy options and strategies, including innovative approaches, toward realising gender equality and the empowerment of women;

- Consider and adopt a Ministerial Declaration to realise women's rights for an equal future, which will serve as the regional input to the 64th session of the Commission on the Status of Women on the global review of the implementation of the Beijing Declaration and Platform for Action" (UNESCAP, 2019d:4).

More than 600 participants from 54 countries, comprising representatives from Governments, international organisations and civil society organisations attended the conference. The delegations reviewed the "achievements, challenges and priority areas for realizing gender equality and women's empowerment" (UNESCAP, 2019a:1) in the Asia-Pacific region.

This latest edition of Asia-Pacific Ministerial Conference provided a vibrant platform for a multitude of diverse stakeholders to reflect on the critical issues concerning gender equality in six thematic areas: "Inclusive development, shared prosperity and decent work; Poverty eradication, social protection and social services; Freedom from violence, stigma and stereotypes; Participation, accountability, gender-responsive institutions; Peaceful and inclusive societies; and Environmental conservation, climate action and resilience-building" (UNESCAP, 2019d:1). After three days of intensive discussions and negotiations, the 'Asia-Pacific Declaration on Advancing Gender Equality and Women's Empowerment: Beijing +25 Review' was adopted as the outcome document of the conference (UNESCAP, 2019c).

Though born in the 1990s-the decade that Nobel Laureate Joseph Stiglitz termed as the 'Roaring Nineties' (Stiglitz, 2003), the 'Beijing Platform for Action' has been hailed as the most progressive policy blueprint for gender equality and women's empowerment. It is an ambitious and comprehensive agenda covering 12 critical areas of concern in almost every aspect that one needs to look deep into whilst examining the various dimensions of gender equality worldwide. These 12 critical areas of concern are: women and poverty; education and training of women; women and health; violence against

\footnotetext{
${ }^{1}$ Space and Culture, India published a review of Beijing+20; see Sharma (2015).
} 
women; women and armed conflict; women and the economy; women in power and decisionmaking; the institutional mechanism for the advancement of women; human rights of women; women and the media; women and the environment; and the girl-child (United Nations, $1995: 16-17)$. That is why, every five years, there has been a global review of its implementation to discuss progress and challenges and identify the way forward. In the review process, regional and national reviews have played and continue to play a critical role in gathering data, conducting analyses, and providing feedback through consultations with key stakeholders. The remainder of the article is divided into two sections. The next section discusses the progress made, and current challenges related to achieving gender equality in the Asia-Pacific region. Following this, it presents some perspectives emerging from the 'Asia-Pacific Declaration on Advancing Gender Equality and Women's Empowerment: Beijing+25 Review'.

\section{Progress and Challenges toward Gender Equality in Asia-Pacific}

For 25 years, since the adoption of the Beijing Platform for Action, Asia-Pacific has witnessed significant progress in girls' education and women's health. However, there are some enduring challenges, including violence against women, women's economic and political empowerment, and their effective participation in environment conservation, climate action and peacebuilding process.

\section{Women's Economic Empowerment and Political Participation}

There is a large gender gap in economic participation. In 2018, just about half of women of 25 years old and above participate in the labour market, compared with $84 \%$ of men of the same age group (UNESCAP, 2019a). The female labour force participation rate went down from $55 \%$ in 1995 to $50 \%$ in 2018 . Further, the femalemale ratio of labour force participation for the Asia-Pacific region, which rose between 1990 and 2000, has declined over the past 20 years (Figure 1). In 2020, the Pacific subregion featured the highest female-male ratio of labour force participation across subregions whilst South and South-West Asia recorded the lowest. Further, the female-male ratio of labour force participation declined in North and North-East Asia, and North and Central Asia subregions during 2015-2020. Women are overrepresented in vulnerable employment, with little or no social protection.

Entrepreneurship is a crucial pathway for women's economic empowerment. However, they face additional barriers when they endeavour to start and expand business due to lack of economic resources and traditional social bias. In Asia-Pacific, "27 countries have supported women's entrepreneurship and business development activities" (UNESCAP, 2019a:9), including enhancing women's financial inclusion, and access to credit and technology.

While the female labour force participation appears to be declining, the irony is that women in Asia and the Pacific work (paid and unpaid work combined) the most prolonged hours in the world. "On average, women in the region did four times the amount of unpaid care work that men did" (UNESCAP, 2019a:7; Figure 2). A recent report noted that "the unpaid care work undertaken by women in Asia Pacific, if included in the measurement of GDP, would add [US] \$3.8 trillion to the regional total, equivalent to roughly 15 percent of the region's GDP" (McKinsey Global Institute, 2018:2). The burden of unpaid care and domestic work has severe implications for women's economic and political participation. 




Figure 1: Female-Male Ratio of Labour Force Participation in Asia-Pacific: 1990 to 2020 Source: Prepared by the Authors based on SDG Gateway Data (UNESCAP, 2020)

The Beijing+25 Review has shown that Governments in the region are taking actions to improve social protection. "To ease the burden of unpaid work, 24 countries have introduced or strengthened various types of family leave. Family leave provides significant benefits to working mothers, as well as their children, partners, families and communities. Forty-four countries in the region mandate maternity leave, while 14 countries mandate paternity leave" (UNESCAP, 2019a:7). However, this is far from enough to redistribute unpaid care work and liberate women from the heavy burden.

Another critical area for advancing the agenda of gender equality is women's participation in public life and decision-making. Regarding their political empowerment, women around the world are "severely under-represented" (WEF, 2019:10). Latest statistics show that the average political participation of women has increased in the Asia-Pacific region; for example, three countries (Nepal, New Zealand and Timor-Leste) have achieved over $30 \%$ of women's representation in national parliaments (Figure 3). While more women are entering politics, the female representation in the national parliaments in the Asia-Pacific region is still low at $20 \%$, which is well below the world average of $24 \%$. In regard to local governments, India and Nepal feature over $40 \%$ women's representation (Figure 3). 


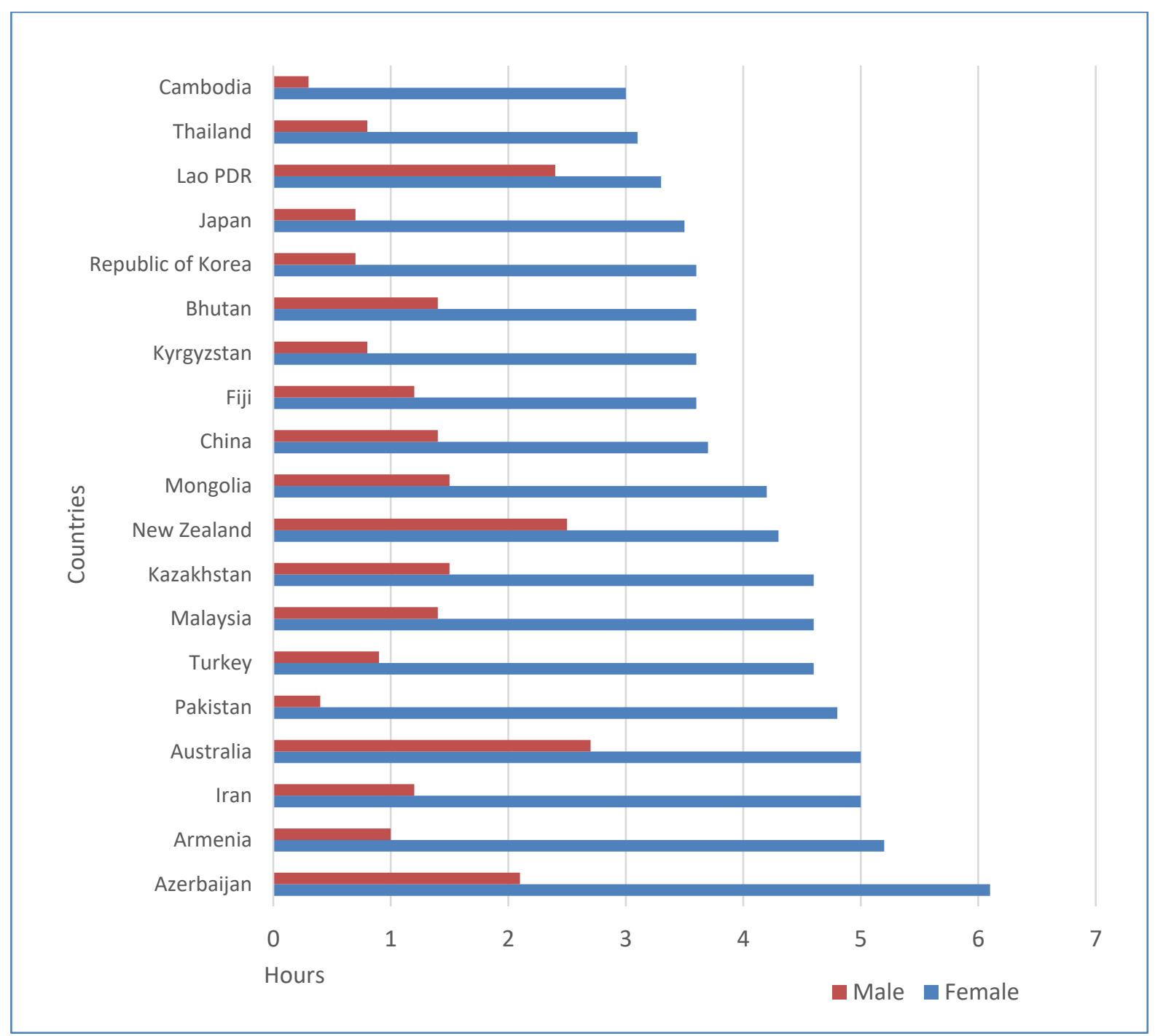

Figure 2: Hours spent on unpaid care and domestic work in Asia-Pacific: 2008 onwards Source: Prepared by Authors based on UN Statistics Division SDG Indicators Database (https://unstats.un.org/sdgs/indicators/database/) 


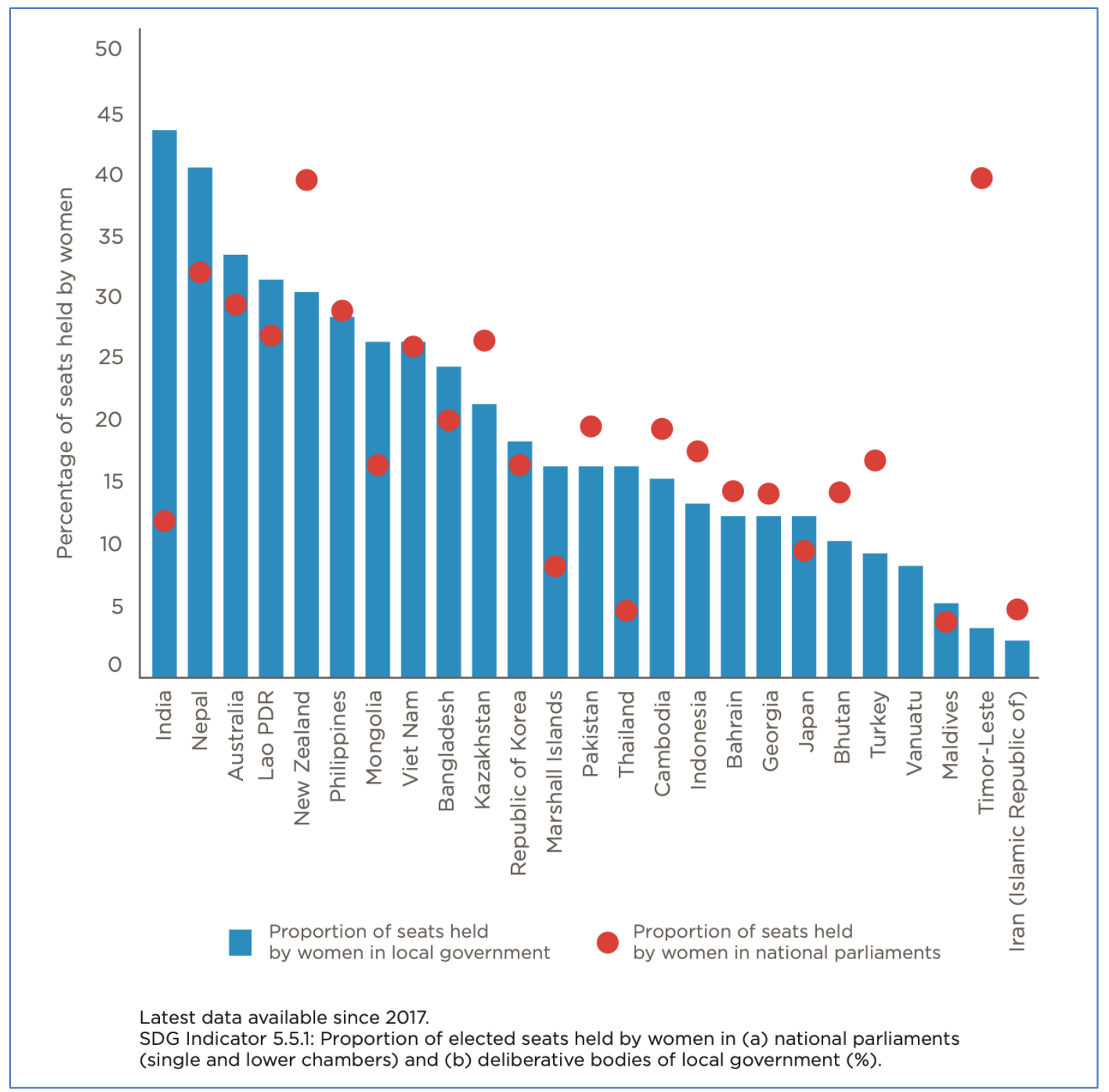

Figure 3: Women's Representation in National Parliaments and Local Governments in AsiaPacific: 2017 onwards

Source: UN Women (2019:2)

A number of countries in the Asia-Pacific region have taken essential steps to promote women's participation in public life and decision-making. These initiatives include (i) implementation of capacity-building and skills-development initiatives (22 countries); (ii) collection and analysis of data on women's political participation (22 countries); (iii) provision of opportunities for mentorship and training in leadership, decision-making, public speaking, self-assertion and political campaigning (20 countries); and (iv) reforming of constitutions, laws and regulations (17 countries) (UNESCAP, 2019a:14).In general, countries with a quota system have better representation of women in parliament than those without (UNESCAP, 2019b).

\section{Education, Health and Violence against Women}

The Beijing+25 Review noted that the "AsiaPacific region has made significant progress towards achieving gender parity in primary education enrolment and is nearing parity at secondary and tertiary levels" (UNESCAP, 2019a:10). However, there is a variation among different subregions of Asia-Pacific. In South Asia, boys are more likely to complete secondary 
school than girls; in South-East Asia, girls are more likely to complete secondary school than boys in most countries. Overall, the gain in gender equality in education enrolment has not translated into employment and further training. Throughout the Asia-Pacific region, fewer girls (15-24 years) than boys are in employment, education and training (UNICEF, 2019).

The Asia-Pacific countries have made significant progress in reducing maternal mortality ratios (MMR), with the average MMR across the region decreased by $61 \%$ during $1995-2015$ from 295 to 115 per 100,000 live births (UNESCAP, 2020). This improvement is positively correlated with the improved access to maternal care, as seen in the proportion of births attended by skilled health personnel increased from $63.6 \%$ in 2000 to $87 \%$ in 2016 . However, in South and SouthWest Asia, the MMR still stands at 170.8 per 100,000 live births (2015), which accounts for almost one-third of the global maternal deaths (UNESCAP, 2019e; Figure 4).

Globally, surveys conducted in 87 countries (including 30 from developed regions) during 2006-2016 showed that "19 per cent of girls and women aged 15 to 49 said they experienced physical and/or sexual violence by an intimate partner in the 12 months prior to the survey" (United Nations Statistics Division, 2020). According to UN Women, Corona Virus Disease (COVID-19) has resulted in a 'shadow pandemic' with an increase in violence against women and girls (Mlambo-Ngcuka, 2020).

In countries across Asia and the Pacific, surveys indicate that between $15 \%$ and $68 \%$ of women have experienced physical or sexual violence at the hands of an intimate partner. Child marriage is still widespread, especially in South Asia, with the highest prevalence at 30\% (UNESCAP, 2019e). The Beijing+25 Review shows that Governments have given priority to addressing violence against women and girls. "In 2018, 47 countries in Asia and the Pacific had dedicated legislation on domestic violence, and 13 countries had developed national action plans on violence against women and/or domestic violence" (UNESCAP, 2019a:12). However, a lot more needs to be done to make the world a safe place for women and girls.

\section{Gender Equality and Environmental Sustainability}

Women have played a pivotal role not only in protecting the environment but also in the management of natural resources and the economic activities based on them (Dahiya, 2003; Encyclopædia Britannica, 2020; Shiva and Bandyopadhyay, 1986; UNESCAP, 2017; Yale Forum on Religion and Ecology, 2020). Asia and the Pacific has been the most disaster-prone region in the world (UNESCAP, 2019f). "According to the International Disaster Database (EM-DAT), between 1980-1989 and 1999-2009, the number of disaster events reported globally increased from 1,690 to 3,886. Over the whole period of 1980-2009, 45 per cent of these were in Asia and the Pacific" (UNESCAP, 2010:2). "Environmental depletion and climateinduced changes have a disproportionate impact on women and add increased pressures on women's time, income, health, nutrition and social support systems" (UNESCAP, 2019a:17). However, women have been underrepresented in environment-related decision making and negotiations at the international level.

There have been some recent improvements in the integration of gender concerns in international agreements and frameworks on climate change. While the Paris Agreement (UNFCCC, 2015) contains limited references to gender, the Gender Action Plan of the United Nations Framework Convention on Climate Change (UNFCCC, 2019) has aimed to bridge this gap. More specifically, it has committed to better-integrating gender in climate change mitigation and adaptation policies and increasing women's participation in climate change policy. 


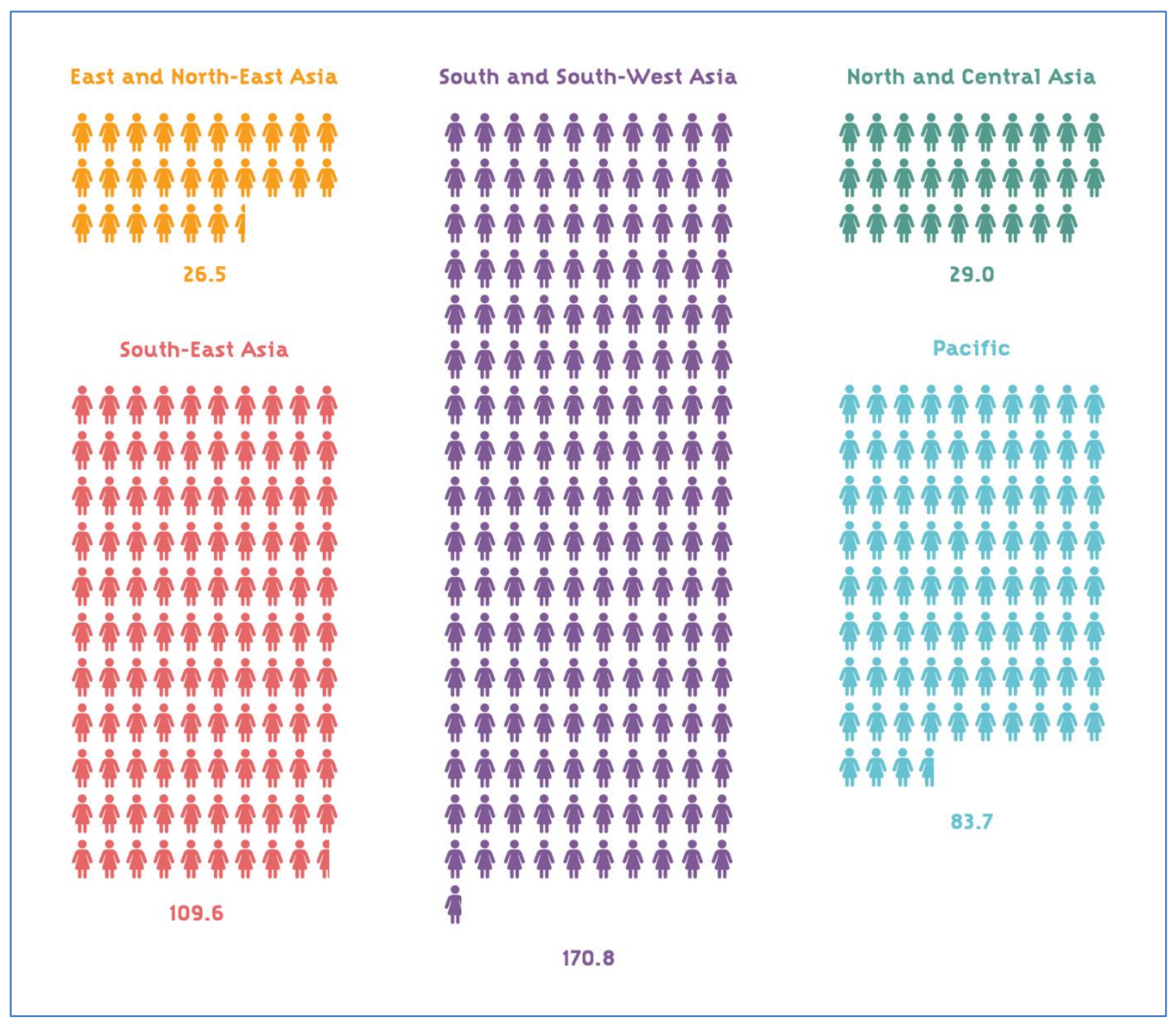

Figure 4: Maternal Mortality Ratios in Asia-Pacific by Subregion Source: UNESCAP (2019e:34)

For women's needs to be considered and included in climate change policy, women also need to be able to voice their concerns and, in particular, need to be represented in climate change decision making. At present, women's representation in climate change diplomacy in the Asia-Pacific region remains low (UNESCAP, 2017). The situation needs to be changed for empowering women for more stringent policies to address climate change impacts.

A number of countries in the Asia-Pacific region have made efforts 'to integrate gender concerns into environmental policies' by (i) supporting women's participation and leadership in environmental and natural resource management and governance ( 25 countries); (ii) promoting the education of women and girls in science, engineering, technology and disciplines relating to the natural environment (16 countries); and (iii) increasing women's access to and control over land, water, energy and other natural resources (15 countries) (UNESCAP, 2019a:17).

Evidence shows that women's participation and leadership in environmental and natural resource management is key to the sustainable management of resources and protection of the environment. In several countries, empowering women in local decision-making concerning the conservation of forests and fisheries leads to better resource efficiency and conservation. In Nepal, its Community Forest Development Programme adopted an affirmative action toward achieving equal, that is, " $50 \%$ representation for women and proportional representation of Dalits, ethnic and marginalized 
communities in Executive Committees of Community Forest Users Groups" (emphasis original; Government of Nepal, 2019:57). Decisions have to be taken in a participatory manner. As of $2019,37 \%$ of the 244,000 committee members of the community forest user groups are women (Government of Nepal, 2019).

\section{Emerging Perspectives}

Given the challenges of gender equality discussed in the previous section, much more needs to be done in the Asia-Pacific region. The 'Asia-Pacific Declaration on Advancing Gender Equality and Women's Empowerment: Beijing+25 Review' (UNESCAP, 2019c) stressed the urgent need to address intersectional barriers and the underlying gender inequalities prevailing in many countries; it called upon Governments, with the support of all relevant stakeholders, to intensify actions to realise women's equal enjoyment of human rights and fundamental freedoms for an equal future by 2030.

Key actions outlined by the 'Asia-Pacific Declaration on Advancing Gender Equality and Women's Empowerment: Beijing+25 Review' cover a wide range of issues, from women's economic empowerment, political participation, to women's full and effective participation in environment conservation, climate action and peacebuilding process.

In 2015, the United Nations' General Assembly adopted the 2030 Agenda for Sustainable development (United Nations, 2015). The global community has committed itself to attain the Sustainable Development Goals (SDGs), including SDG 5 that aims to "achieve gender equality and empower all women and girls" (United Nations, 2020b). In view of this, a worthwhile question to ask is:

By 2030, what should be the key features of gender equality in Asia-Pacific? The following would be what the Asia-Pacific region strives to achieve:

Women spend less time on unpaid care work, and more time on productive and leisure activities. To make this happen, a universal social care infrastructure that takes care of children and the elderly is vital. Women and men enjoy an equal and mutually supportive relationship at home and in the public domain.

More women assume the leadership positions in the corporate world, and women entrepreneurs enjoy equal access to capital, market and technology. More women take on decision making roles in the government, to become and act as policy or lawmakers. And women are active change agents in environment conservation and climate action.

All women and girls live in a world with respect and free from violence.

In sum, when we reflect on the progress in people, planet and prosperity at the fifth anniversary of the adoption of SDGs, we must not forget that the advancement of gender equality and women's empowerment would have a decisive impact on the success or failure of the 2030 Agenda for Sustainable Development.

\section{References}

Dahiya, B. (2003). Hard Struggle and Soft Gains: Environmental Management, Civil Society and Governance in Pammal, South India, Environment \& Urbanization, 15(1), 91-100. https://doi.org/10.1177/095624780301500108

Encyclopædia Britannica (2020). Chipko movement: Indian Environmental Movement. https://www.britannica.com/topic/Chipkomovement

Government of Nepal (2019). Submission for the Twenty-fifth Anniversary of the Fourth World Conference on Women and Adoption of Beijing Declaration and Platform for Action (1995). https://www.unwomen.org/-

/media/headquarters/attachments/sections/cs w/64/national-reviews/nepal.pdf

McKinsey Global Institute (2018). The Power of Parity: Advancing Women's Equality in Asia Pacific. McKinsey and Company: New York. Mlambo-Ngcuka, P. (2020). Violence against Women and Girls: The Shadow Pandemic. https://www.unwomen.org/en/news/stories/2 
020/4/statement-ed-phumzile-violence-againstwomen-during-pandemic

Sharma, A. (2015). Beijing+20: Some Musings. Space and Culture, India, 2(4), 1-2.

https://doi.org/10.20896/saci.v2i4.127

Shiva, V. and Bandyopadhyay, J. (1986). Chipko: India's Civilisational Response to the Forest Crisis. INTACH: New Delhi.

Stiglitz, J.E. (2003). The Roaring Nineties: A New History of the World's Most Prosperous Decade. W.W. Norton \& Company: New York.

United Nations. (1995). Beijing Declaration and Platform for Action.

https://www.un.org/en/events/pastevents/pdf s/Beijing_Declaration_and_Platform_for_Action .pdf

United Nations (2015). Transforming Our World: The 2030 Agenda for Sustainable Development.

A/RES/70/1.https://sustainabledevelopment.un .org/post2015/transformingourworld/publicati on

United Nations (2020a). Fourth World

Conference on Women (September 1995,

Beijing, China).

https://www.un.org/en/events/pastevents/wo men_conf_beijing_1995.shtml

United Nations (2020b). Goal 5: Achieve Gender Equality and Empower all Women and Girls. https://www.un.org/sustainabledevelopment/g ender-equality/

United Nations Statistics Division (2020). Goal 5: Achieve Gender Equality and Empower all Women and girls.

https://unstats.un.org/sdgs/report/2017/goal05/

UNESCAP (2010). Protecting Development Gains: Reducing Disaster Vulnerability and Building Resilience in Asia and the Pacific. The Asia-Pacific Disaster Report, 2010. UNESCAP: Bangkok.

UNESCAP (2017). Gender, the Environment and Sustainable Development in Asia and the Pacific. https://www.unescap.org/sites/default/files/pu blications/SDD-Gender-Environment-report.pdf

UNESCAP (2019a). Review of the Progress and Remaining Challenges in Implementation of the Beijing Declaration and Platform for Action in Asia and the Pacific.

https://www.unescap.org/sites/default/files/Re view_of_progress_\%28ENG\%29.pdf

UNESCAP (2019b). Pathways to Influence:

Promoting the Role of Women's Transformative Leadership to Achieve the SDGs in Asia and the Pacific. Sales No.E.20.II.F.4.

UNESCAP (2019c). Asia-Pacific Declaration on Advancing Gender Equality and Women's Empowerment: Beijing+25 Review.

ESCAP/MCBR/2019/2/Add.1.

https://www.unescap.org/sites/default/files/Be ijing\%2B25-Declaration-\%28ENG\%2920200220.pdf

UNESCAP (2019d). Concept Note: 25th Anniversary of the Beijing Declaration and Platform for Action - Asia-Pacific Ministerial Conference on the Beijing+25 Review. https://www.unescap.org/sites/default/files/Be ijing\%2B25\%20Regional\%20Review\%20Concept \%20Note\%2020190716_0.pdf

UNESCAP (2019e). Population and Development in Asia and the Pacific: Lessons learned from the Midterm Review of the Asian and Pacific Ministerial Declaration on Population and Development. UNESCAP.

UNESCAP (2019f). The Disaster Riskscape across Asia-Pacific: Pathways for Resilience, Inclusion and Empowerment. Asia-Pacific Disaster Report 2019. UNESCAP: Bangkok.

UNESCAP (2020). SDG Gateway Data. https://dataexplorer.unescap.org/

UNFCCC (2015). Paris Agreement. FCCC/CP/2015/L.9/Rev1.

http://unfccc.int/resource/docs/2015/cop21/e ng/l09r01.pdf

UNFCCC (2019). Enhanced Lima work programme on gender and its gender action plan. UNFCCC. Conference of the Parties. https://unfccc.int/topics/gender/workstreams/t he-gender-action-plan 
UNICEF (2019). Gender Counts (4 Subregional Reports for Asia and the Pacific).

https://data.unicef.org/

UN Women (2019). Gender Equality in Asia and the Pacific: 25 Years After The Beijing

Declaration.

https://asiapacific.unwomen.org/en/digitallibrary/publications/2019/11/infographicsgender-equality-in-asia-pacific
WEF (2019). Global Gender Gap Report 2020. World Economic Forum: Geneva.

Yale Forum on Religion and Ecology (2020).

Chipko Movement.

https://fore.yale.edu/World-

Religions/Hinduism/Engaged-Projects/ChipkoMovement 